\title{
IMPLEMENTASI TECHNOLOGICAL PEDAGOGICAL CONTENT KNOWLEDGE SEBAGAI MODERNISASI DI BIDANG PENDIDIKAN
}

\author{
Nayla Rizqiyah ${ }^{1 *}$ \\ 1)Pendidikan Guru Sekolah Dasar, Fakultas IImu Pendidikan, Universitas Pendidikan Indonesia \\ *Penulis Korespondensi: nayla@upi.edu*
}

\begin{abstract}
Abstrak
Technological Pedagogical Content and Knowledge (TPACK) ialah suatu model pembelajaran yang relative baru dalam dunia pendidikan. Praktik pelaksanaan metode ini mencakup penguasaan teknologi, pedagogic dan pengetahuan mengenai konten pembelajaran. Pengumpulan data dimaksudkan untuk memperoleh data yang akurat dan obyektif melalui observasi pada mahasiswa Universitas Pendidikan Indonesia Kampus Bumi Siliwangi dan Kampus Cibiru, untuk menelusuri implementasi TPACK dalam kegiatan pembelajaran dengan menyebarkan survei kepada 20 orang mahasiswa secara acak. Hasil penelitian akan dipaparkan dengan menggunakan metode deskriptif kuantitatif, data yang terhimpun direpresentasikan dengan diagram dan rangkaian kata-kata yang merujuk pada suatu kesimpulan atau generalisasi. Implementasi TPACK di Universitas Pendidikan Indonesia telah menunjukan adanya transisi dari berbagai komponen TPACK yang sudah diterapkan, namun belum mencapai keefektivan yang maksimal. Berdasarkan penelitian yang telah dilakukan, TPACK sudah terimplementasi dalam tingkat 'cukup baik' di Universitas Pendidikan Indonesia. Diharapkan penelitian ini dapat menjadi evaluasi dan bahan pengembangan penelitian lain, pengajar, maupun pemerintah mengenai metode pembelajaran dan untuk menelusuri pemanfaatan kemajuan teknologi sebagai modernisasi di bidang pendidikan khususnya di perguruan tinggi.
\end{abstract}

Keywords: modernisasi, TPACK, pendidikan Indonesia

Informasi Artikel:

Artikel Diterima: 21 Mei 2021

Artikel Direvisi: 10 Juni 2021

Artikel Disetujui: 17 Juni 2021 


\section{PENDAHULUAN}

Indonesia

merupakan

negara

berkembang yang mulai mengubah kebiasaan konvensional dengan teknologi, segala hal dalam proses modernisasi. Perkembangan ini tidak hanya terjadi pada satu bidang saja, namun berbagai bidang seperti sektor ekonomi, proses produksi, sektor pangan, bahkan pendidikan. Modernisasi bukanlah hal yang buruk, modernisasi hadir membawa berbagai manfaat dan kerusakan tergantung pada siapa yang memanfaatkannya. Bidang pendidikan merupakan salah satu bidang yang memiliki modernisasi yang cukup pesat dibandingkan dengan bidang lainnya. Terutama saat adanya tuntutan terhadap para siswa. Berbagai kompetensi harus dikuasai oleh generasi muda Indonesia supaya tidak tertinggal oleh kemajuan zaman. Salah satunya untuk bertahan di abad ke-21 ini, generasi muda Indonesia setidaknya memiliki kompetensi tujuh kemampuan survival yang diusungkan oleh Wagner, yaitu: (1) Critical Thinking and Problem Solving; (2) Collaboration Across Networks and Leading by Influence; (3) Agility and Adaptability; (4) Initiative and Entrepreneuralism; (5) Effective Oral and Written Communication; (6) Accessing and Analyzing Information; dan (7) Curiosity and Imagination (Wagner, 2008). Ketujuh kemampuan tersebut bila dikuasai dengan baik akan memberikan kesuksesan dan keberhasilan untuk bertahan dan berinovasi dalam persaingan hidup yang semakin ketat. Bila dibedah dan dianalisis satu persatu, untuk melatih kemampuan-kemampuan bertahan di abad-21 ini dapat ditemukan dalam pembelajaran di perguruan tinggi baik secara terintegrasi dengan mata kuliah, penugasan dan diskusi saat belajar.

Keberhasilan dari proses pembelajaran sangat ditentukan dari bagaimana para pendidik mengatur kelas. Kemajuan teknologi yang makin pesat seharusnya diiringi dengan kemampuan memperkirakan keefisiensian dan ketepatan metode pembelajaran sehingga tujuan pembelajaran dapat tercapai. Selain itu, konteks pembelajaran dan kurikulum di abad-21 ini harus selalu mengikuti perubahan peradaban yang ada. Termasuk di masa revolusi industry 4.0 dimana generasi muda harus memiliki keterampilan abad-21 dengan baik supaya tidak tertindas oleh zaman (Kusumah, 2019). Generasi muda yang tidak produktif akan

Selain generasi muda yang harus meningkatkan kemampuan mereka, para pendidik juga memiliki tugas yang tak kalah beratnya dalam mempersiapkan generasi muda yang berkompetensi. Pendidik jika dimaknai menurut sistem pendidikan Indonesia, merupakan seorang professional yang memiliki tugas mendidik, mengajar, membimbing, mengarahkan, melatih, menilai dan memberi evaluasi peserta didik baik dalam jalur pendidikan formal maupun non-formal (pasal 1 ayat 1 UU No.14 Tahun 2005). Pengembangan profesionalitas pendidik untuk dapat mengimplementasikan metode pembelajaran yang semakin maju sejatinya bergantung pada kemauan pendidik itu sendiri dalam melabeli standar profesionalitas dirinya (Risdiany \& Herlambang, 2021). Pendidik sebagai sumber 
ilmu utama yang ada di bangku sekolah mesti menguasai teknologi untuk menyampaikan pembelajaran dengan media yang lebih inovatif, kreatif dan mengundang rasa ingin tahu siswa sehingga siswa dapat bereksplorasi dan berpikir kritis, diharapkan siswa dapat menemukan suatu penemuan baru. Selain itu, metode pembelajaran yang sesuai dan selaras dengan materi pembelajaran yang akan disampaikan akan menciptakan pemahaman yang baik dan kondisi kelas yang kondusif, dengan ini dibutuhkan adanya keterampilan pedagogic dalam diri pendidik. Keterampilan lainnya adalah bagaimana pendidik menguasai materi pembelajaran, tidak hanya secara kontekstual seperti yang tertulis di dalam buku pembelajaran, namun pendidik haruslah dapat menjadi sosok 'gudang ilmu' yang memiliki wawasan luas menganai hal-hal yang dapat membantu siswa menemukan ide-ide dan pemikiran baru.

\section{Hadirnya TPACK (Technological} Pedagogical and Content Knowledge) menandai adanya era baru dan proses kemajuan dalam dunia pendidikan. TPACK merangkum berbagai kebutuhan keterampilan oleh pendidik di era modernisasi. Teknologi, pedagogic dan pengetahuan konten adalah elemen utama dalam TPACK. Pendidik yang mampu menguasai TPACK dan mengintegrasikan dengan pembelajaran akan menghadirkan komparasi opini yang berbeda dengan pendidik yang belum mampu dalam menguasai TPACK. Penerapan TPACK salah satunya akan diketahui dari hasil pengumpulan data survei terhadap beberapa mahasiswa di salah satu perguruan tinggi, yaitu Universitas Pendidikan Indonesia. Melalui hasil penilaian penerapan TPACK akan diketahui kekurangan dan evaluasi apa saja yang perlu dilakukan demi melangsungkan modernisasi dalam bidang pendidikan supaya pembelajaran menjadi lebih efektif dan sesuai dengan perkembangan zaman. Hasil data survei menunjukan perbedaan opini sehingga penarikan kesimpulan perlu menggunakan metode kuantitatif guna meningkatkan akurasi pengolahan data. Situasi pandemi covid-19 yang mengharuskan social-distancing membuat survei dilakukan secara online.

\section{TINJAUAN PUSTAKA}

\section{Mengenai Modernisasi}

Globalisasi dan modernisasi adalah dua hal yang tidak dapat dipisahkan. Dua hal tersebut berjalan berkesinambungan dan saling berkaitan satu sama lain. Modernisasi adalah salah satu bagian atau proses menuju globalisasi. Globalisasi mencakup berbagai aspek dalam kehidupan, termasuk cara berpikir dan ideology dalam suatu masyarakat internasional. Jika suatu masyarakat atau individu menghindari adanya globalisasi dan modernisasi, maka mereka memilih untuk mengucilkan diri dari lingkup kehidupan masyarakat internasional (Nasution, 2017). Istilah modernisasi atau proses pembaharuan sosial ini memiliki sangkut paut dengan adanya revolusi Industri di Inggris (1760-1830) juga revolusi yang terjadi di Prancis (1789-1794) adalah dua kejadian yang mempelopori adanya modernisasi di dunia (Iskandar, 2018). 
Modernisasi sendiri dalam Kamus Besar Bahasa Indonesia, merupakan sebuah kata yang mendapat imbuhan -isasi dari kata dasar modern. Yang maknanya adalah terbaru, mutakhir atau sikap dan cara berpikir yang sesuai dengan tuntutan zaman. Koentjaraningrat mengartikan modernisasi sebagai sebuah usaha secara sadar dilakukan suatu bangsa atau negara bertujuan untuk beradaptasi dengan konstelasi dunia pada periode waktu tertentu di masa suatu bangsa. Modernisasi secara sederhana dapat dipahami sebagai proses perubahan dari sistem tradisional menuju masyarakat yang bersifat modern yang bertujuan untuk meraih kesejahteraan masyarakat.

Modernisasi seringkali diserupakan dengan proses westernisasi. Padahal menurut definisinya, westernisasi merupakan perilaku mengadaptasi atau mengimitasi life style orang Barat. Definisi lain modernisasi sendiri merupakan sebuah perubahan yang tidak bisa dihentikan dan dihindari. Modernisasi bukan hanya ada pada bidang tertentu, namun cakupannya lebih general melingkupi pembaharuan pada sesuatu yang dipandang sudah lama dan berusaha menggantinya dengan ideology dan situasi yang baru. Beberapa sifatsifat dari modernisasi adalah rasional, ilmiah, dan kesesuaian hokum-hukum yang berlaku di alam. Dampak-dampak dari modernisasi dalam kehidupan tak dapat dihindarkan, dampak modernisasi (Matondang, 2019) adalah sebagai berikut.

\section{a. Dampak Positif}

Modernisasi tak lepas dari adanya kemajuan IPTEK sebagai pendukungnya. Dengan adanya kemudahan dari teknologi, manusia dapat mempermudah kesehariannyaa termasuk dalam bertukar informasi. Berdampak adanya perubahan kebiasaan dan kebudayaan dalam masyarakat. Ideology masyarakat yang mulanya memiliki pemikiran konvensional akan berpikir lebih maju dan rasional. Kemudahan ini juga berdampak pada keadaan perekonomian dan kesejahteraan masyarakat yang bergerak ke arah yang lebih baik. Pembaharuan dari proses produksi dan distribusi tradisional yang menghabiskan biaya modal akan berkurang apabila modernisasi diterapkan untuk mengefisiensikan prosedur dan peralatannya.

\section{b. Dampak Negatif}

Sebaliknya, adanya kemajuan akibat modernisasi menyebabkan arus informasi mengalir seperti arus dan terkadang diterima tanpa melalui proses pengecekan kembali atau filtrasi sehingga informasi yang buruk berpotensi dapat merusak ideology, moral dan kebudayaan bangsa. Gaya hidup yang semakin bercampur dengan gaya hidup kemewahmewahan membuat masyarakat cenderung menjadi konsumtif. Karena tuntutan gaya hidup yang mewah akan membuat orang menghalalkan berbagai cara untuk menghilangkan kesenjangan sosial yang ada sehingga akan menaikan persentase kriminalitas yang ada. Selain itu, dengan adanya modernisasi pada proses produksi dapat mengakibatkan adanya pencemaran jika tidak adanya pengetahuan pengolahan limbah yang baik. 
Globalisasi mendorong adanya modernisasi di dunia pendidikan. Modernisasi dalam bidang pendidikan seringkali dikaitkan dengan perkembangan media pembelajaran. Namun, seiring modernisasi pendidikan yang dilakukan, masih terdapat kesenjangan pendidikan yang terjadi di Indonesia. Pembiayaan pendidikan memang telah merata dan sekolah di Indonesia tidak dikenai biaya, hal itu tidak dapat menjamin mutu pendidikan menjadi semakin layak (Primadata \& Kusumawati, 2014). Pemerintah sebagai tokoh utama dalam sistem pendidikan di Indonesia harus mengembangkan mutu pendidikan melalui pengembangan metode pendidikan yang layak dan sesuai dengan perkembangan zaman. Seperti yang telah dipaparkan bahwa modernisasi mau tidak mau akan terjadi pada berbagai bidang. Setelah adanya 'reparasi' pada kurikulum yang ada. Selanjutnya pembenahan dan peningkatan kemampuan untuk menerapkan kurikulum tersebut agar esensi dan tujuan pengajaran dapat diterima oleh siswa. Perlunya pemahaman mengenai apa yang dibutuhkan oleh generasi muda untuk bertahan di abad-21 ini dan membuat mereka berpikir bahwa masa depan mereka tidaklah menentu (Sudira, 2012). Karena menurut Giddens, modernisasi diibaratkan sebagai kendaraan raksasa yang melaju tanpa henti dan mendorong masyarakat untuk selalu bergerak maju (George, 2000). Era globalisasi cenderung mendukung dan mencondongkan pola perkembangan pendidikan Indonesia pada sisi pendidikan yang bersifat materialistik (Primadata \& Kusumawati, 2014). Sehingga hadirlah integrasi pendidikan karakter untuk mendukung perkembangan moralitas anak di lingkungan sekolah. Pendidikan karakter adalah pendidikan yang mendukung perkembangan sosial, emosional dan etis siswa (Ani, 2014).

\section{Konsep TPACK (Technological Pedagogical Content Knowledge)}

TPACK merupakan sebuah singkatan dari Technological, Pedagogical Content Knowledge. Singkatan tersebut sebenarnya merupakan perwujudan dari tiap-tiap kompetensi pendidik. Meliputi kemampuan menguasai teknologi, kemampuan pedagogic dan penguasaan konten pengetahuan. Hal ini didorong oleh adanya pembaharuan dan moderenisasi yang mengharuskan siswa memiliki tujuh kemampuan bertahan di abad21. Jika penguasaan siswa hanya sebatas kemampuan literasi lama (membaca, menulis dan matematika) akan membuatnya tertinggal dan tertindas oleh zaman. Diperlukan penguasaan literasi manusia dan literasi teknologi untuk mengembangkan diri (Farikah \& Al Firdaus, 2020). Maka diperlukan adanya inovasi baru dalam pembelajaran di Indonesia. TPACK adalah suatu integrasi sistem pembelajaran yang sempurna dimana guru dapat mengorganisir kelas dengan kondusif dan siswa mampu memahami materi atau bahkan berkarya melalui penemuan baru. Pembangunan apersepsi siswa dapat menunjang pemahaman siswa terhadap materi pembelajaran yang disampaikan.

Peningkatan kualitas pembelajaran melalui implementasi TPACK mulai diterapkan secara serius sejak adanya Pandemi Covid-19. 
Diyakini setelah redanya pandemic, perkembangan teknologi secara maksimal dalam pembelajaran akan semakin maju. TPACK merupakan suatu metode yang dikembangkan dari Shulman (Shulman, 1986), gagasan awalnya mengenai Pedagogical Content Knowledge atau disingkat dengan PCK. Selanjutnya pertama kali dipaparkan dalam sebuah jurnal pendidikan di tahun 2003, pada awalnya dikenal sebagai TPCK. Sementara, TPACK merupakan sebuah kerangka teoretis dimana tujuannya adalah untuk menambah pemahaman siswa mengenai materi yang disampaikan, dengan cara mengintegrasikan kemampuan dan aplikasi berbagai bidang.

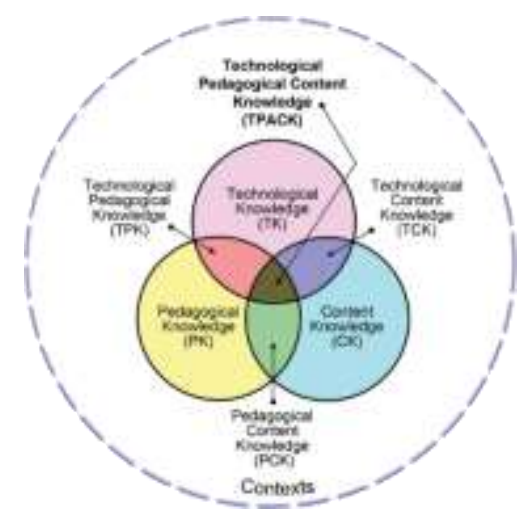

Gambar 1. Technological Pedagogical Content Knowledge (TPACK) Framework (Mishra \& Koehler, 2008)

Pada dasarnya, TPACK (Rahmadi, 2019) merupakan suatu gabungan dari tiga komponen pengetahuan dasar, meliputi Technological Knowledge (TK), Pedagogical Knowledge (PK), dan Content Knowledge (CK). Dari diagram venn yang tersaji dalam gambar, menggambarkan struktur TPACK yang saling ber-relasi dan memiliki keterkaitan berdasarkan beberapa pendapat Mishra \& Koehler (2006 \& 2008), Koehler \& Mishra (2009) dan Koehler, Mishra, \& Cain (2013) yang dikutip oleh (Rosyid, 2017) sebagai berikut.

Technological Knowledge (TK), merupakan pengetahuan dasar mengenai teknologi dan pengoperasian alat-alat perangkat digital. Perlunya penguasaan beberapa media pembelajaran yang berupa mesin bertenaga listrik semisal proyektor, alat-alat laboratorium, pengoperasian sistem computer dan penggunaannya. Penguasaan teknologi dapat mengembangkan media pembelajaran yang ada supaya menjadi lebih menarik, efisien serta interaktif. Misalnya saat melakukan simulasi, untuk menghemat biaya penelitian, pendidik dapat mengarahkan peserta didik untuk melakukan simulasi digital.

Content Knowledge (CK), pengetahuan dasar mengenai disiplin ilmu dan materi pembelajaran perlu dipahami dengan benar oleh para pengajar. Informasi yang semakin menyebar dengan cepat membuat peserta didik leluasa untuk mengeksplorasi lebih. Pendidik sebagai sumber pengetahuan di sekolah mesti memberikan pemahaman yang sesuai dan tidak menimbulkan keambiguan. Kecakapan dalam bidang ilmu juga terkadang membuat pendidikan memiliki kekhasan dalam pemikirannya pada suatu kajian.

Pedagogical Knowledge (PK), pedagogic merupakan kompetensi yang wajib dimiliki oleh seorang pendidik. Peraturan Pemerintah Republik Indonesia Nomor 19 Tahun 2005 secara rinci menjabarkan bahwa kompetensi 
pedagogik merupakan kemampuan seorang guru untuk mengelola pembelajaran yang tersusun atas pemahaman terhadap siswa, perencanaan kelas, implementasi pembelajaran, evaluasi hasil belajar dan mengaktualisasikan segenap potensi siswa. Pengetahuan pedagogic diantaranya meliputi peranan pendidik sebagai motivator peserta didik dan keterampilan untuk memilih metode pembelajaran yang tepat, melakukan penataan atau manajemen kelas agar proses pembelajaran menjadi kondusif.

Pedagogical Content Knowledge (PCK), gagasan ini merupakan gagasan pertama yang dicetuskan oleh Shulman (1986), inti pemikirannya adalah tentang pengajaran efektif yang memisahkan konten pembelajaran dan pedagogic. Kesesuaian antara metode pembelajaran, manajemen pengaturan kelas dan materi yang disampaikan akan membuat konstruksi pemahaman menjadi lebih mudah diterima. Contohnya ketika pembelajaran eksak atau matematika, maka metode pembelajaran yang lebih tepat adalah dengan menggunakan metode ceramah atau ekspositori sehingga dasar teori dapat dipahami dengan baik. Selanjutnya, peserta didik dapat mengembangkan pengetahuannya dengan bantuan guru.

Technological Content Knowledge (TCK), meliputi penguasaan pengetahuan dasar mengenai teknologi dan konten pembelajaran. Teknologi yang semakin menunjukan kemajuan memberikan dampak positif bagi pendidik. Penyampaian materi dapat dilakukan dengan berbagai cara, termasuk dengan memanfaatkan teknologi, namun, media yang menarik jika tidak disertai penguasaan materi yang baik dapat menyebabkan ketidaksesuaian tujuan pembelajaran. Contohnya pada saat guru menggunakan projektor, apabila seorang pengajar belum begitu menguasai materi, ia akan menuliskan keseluruhan materinya di dalam projector tersebut sehingga penggunaan teknologi dalam pembelajaran tidak menjadi efektif.

Technological Pedagogical Knowledge (TPK), menyatukan dua pengetahuan dasar, yaitu teknologi dan pedagogic. Pengetahuan mengenai manajemen penataan kelas dan metode pembelajaran yang tepat membuat pendidik memahami perangkat atau sistem teknologi apa yang tepat dan efektif digunakan untuk mengkonstruksi pemahaman siswa. Bahkan beberapa pendekatan pedagogis dapat semakin berkembang apabila diintegrasikan dengan teknologi.

Technological Pedagogical and Content Knowledge (TPACK), ialah suatu interaksi dan integrasi antara ketiga pengetahuan dasar teknologi, pedagogic dan konten pembelajaran. Pembelajaran dengan metode TPACK akan menunjukan adanya keefektivan karena adanya penguasaan operasi teknologi media pembelajaran yang dibarengi keahlian pengaturan metode pembelajaran dan media yang digunakan. Penguasaan materi oleh guru akan membuat pembelajaran lebih terarah.

\section{METODE PENELITIAN}

Fokus penelitian adalah untuk menganalisis ada tidaknya implementasi TPACK oleh para pendidik. Data dihimpun melalui observasi pada 20 orang mahasiswa di 
Universitas Pendidikan Indonesia Kampus Bumi Siliwangi dan Kampus Cibiru, dengan menyebarkan survei secara acak kepada para mahasiswa menggunakan instrument Google forms. Hasil penelitian akan dipaparkan dengan menggunakan metode deskriptif kuantitatif sehingga data akan disajikan dengan diagram lingkaran dengan jumlah persentase. Selanjutnya, dideskripsikan dengan rangkaian kata-kata yang kemudian merujuk pada suatu kesimpulan atau generalisasi. Penelitian ini bertujuan untuk mengidentifikasi implementasi TPACK oleh tenaga pengajar di salah satu perguruan tinggi Indonesia sebagai proses modernisasi pendidikan.

Hasil penelitian dapat bersifat eclectic atau fleksibel (Ahyar et al., 2020). Diharapkan penelitian ini dapat menjadi bahan dasar data untuk pengembangan penelitian lainnya mengenai metode pembelajaran dan untuk menelusuri pemanfaatan kemajuan teknologi di bidang pendidikan khususnya di perguruan tinggi. Penelitian ini dapat menjadi acuan bagi penyelenggara pendidikan lainnya dalam mengimplementasikan TPACK dalam pembelajaran, juga dapat menjadi evaluasi bagi para pendidik atau pemerintah.

\section{HASIL DAN PEMBAHASAN}

Berdasarkan survei yang dilakukan pada mahasiswa mengenai implementasi TPACK di Universitas Pendidikan Indonesia, menghasilkan beberapa fakta yang dapat menjadi evaluasi terhadap para pendidik. Untuk mengetahui implementasi ketujuh korelasi TPACK dalam pembelajaran.
Guna menganalisis kemampuan dan kecakapan pengajar dalam mengimplementasikan TPACK, maka diperlukan penelusuran yang lebih terperinci dalam penguasaan komponen-komponen dasar TPACK dan menemukan suatu hal yang perlu diperbarui atau diperbaiki untuk menuju modernisasi dalam dunia pendidikan. Komponen TPACK diantaranya: Technological Knowledge (TK), Pedagogical Knowledge (PK), dan Content Knowledge (CK). Terhadap data hasil survei, indikator kemampuan dan kesesuaian diukur dengan skala ordinal. Tingkat pengukuran mampuan dan kesesuaian implementasi TPACK di Universitas Pendidikan Indonesia adalah sebagai berikut:

1. Sudah menguasai/Sudah menerapkan, efektif (warna biru).

2. Cukup menguasai/Sudah menerapkan, belum efektif (warna merah).

3. Belum menguasai/Belum menerapkan (warna kuning).
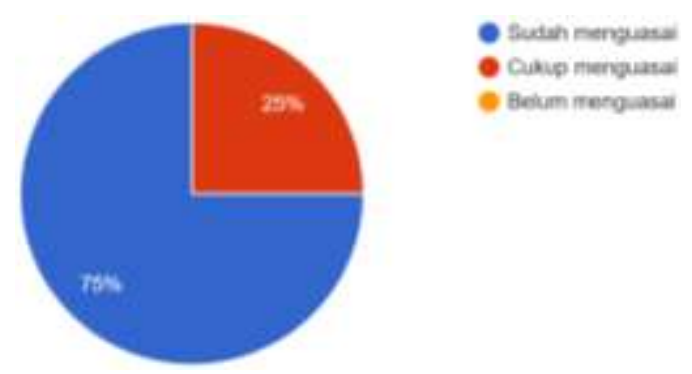

Gambar 2. Persentase penguasaan teknologi oleh pengajar

Technological Knowledge (TK), Tingkat penguasaan teknologi meliputi penguasaan teknologi yang lama, yaitu pengoperasian computer dan alat-alat bantu belajar elektronik dan pembaruan teknologi yang terbaru (seperti 
penggunaan aplikasi conference di masa pandemic covid-19) menunjukan persentase yang cukup tinggi. Persentase opini responden menunjukan bahwa pengajar telah menguasai kemampuan untuk memanfaatkan dan berinovasi dengan teknologi (75\%) dan pengajar yang cukup menguasai teknologi (25\%). Dalam data uraian hasil survei, menyatakan penguasaan teknologi yang cukup, menandakan pengajar masih dalam tingkatan sistem perangkat yang sederhana seperti penggunaan aplikasi untuk ujian harian, penampilan materi dengan aplikasi power point.

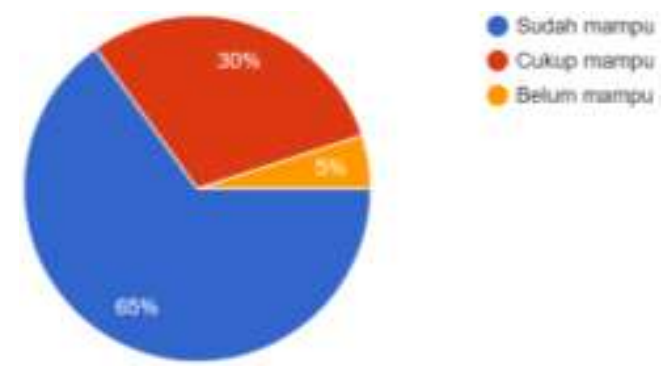

Gambar 3. Persentase kemampuan implementasi pedagogik pengajar

Pedagogical Knowledge (PK), berdasarkan hasil survei menunjukan 13 mahasiswa berpendapat pengajar sudah mampu (65\%), serta 6 orang menyatakan pengajar cukup mampu mengimplementasikan pedagogik untuk memanajemen kelas maupun kecakapan memilih metode pembelajaran $(30 \%)$. Namun terdapat 1 mahasiswa yang menyatakan pengajar belum mampu menerapkan keterampilan pedagogik dalam pengajaran dengan efektif (5\%). Jika diakumulasikan, maka akan ada 19 orang menyetujui kemampuan pendidik dalam pedagogic telah mencapai hasil yang baik. Maknanya, pengajar cukup memahami bagaimana mengorganisir kelas dan mengadakan pembelajaran yang terstruktur yang memperhatikan murid, sebagian besar diantaranya telah mampu mengorganisir pembelajaran hingga menambah keefektivan pembelajaran.
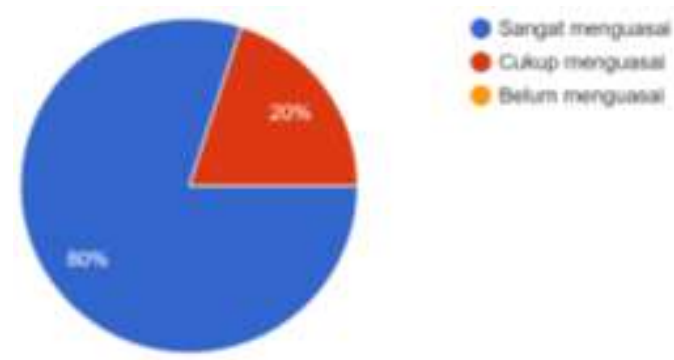

Gambar 4. Persentase penguasaan materi oleh

$$
\text { pengajar }
$$

Content Knowledge (CK), Tingginya persentase menunjukan penguasaan konten materi yang tinggi oleh pengajar $(80 \%)$, dan penguasaan konten materi yang cukup sebesar (20\%). Responden memberikan tanggapan bahwa pengajar yang sangat menguasai konten pembelajaran yang dilakukan akan mengajar sesuai dengan bahan ajar atau kurikulum yang telah ditetapkan, pendidik saat menjelaskan tidak hanya terpaku dengan bahan ajar, namun dengan pendekatan lain sehingga mahasiswa dapat memahami maksud pembelajaran dan dapat mengimplementasikan pengetahuannya tersebut.

Kemampuan pendidik untuk menjawab pertanyaan-pertanyaan saat diskusi dengan mahasiswa dinilai cukup memuaskan. Menunjukan penguasaan di disiplin ilmunya telah matang dan pemahaman mengenai konsep pembelajaran yang sangat baik. 


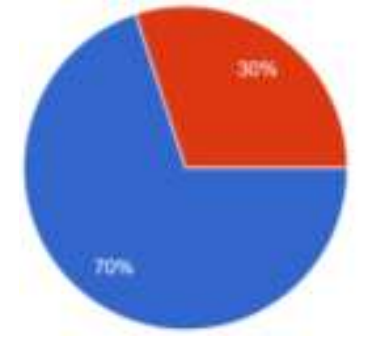

Gambar 5. Persentase implementasi TPK pengajar

Technological Pedagogical Knowledge (TPK), merupakan gabungan penguasaan antara kompetensi pengetahuan teknologi dan pedagogik yang dimiliki oleh pendidik. TPK merupakan pengetahuan dasar mengenai cara berbagai teknologi dapat dimanfaatkan dalam proses pembelajaran dan penggunaan teknologi yang terintegrasi mampu mengubah cara guru mengajar (Schmidt et al., 2009). Persentase sebanyak 14 mahasiswa menyetujui bahwa pengajar telah mampu memilih dan menguasai sistem teknologi berdasarkan pendekatan metode pembelajaran yang digunakannya $(70 \%)$. Sisanya, mahasiswa berpendapat penggunaan media atau teknologi oleh pengajar telah menunjukan kesesuaian dengan metode pembelajaran yang dipilih, namun belum ada pengembangan lebih lanjut (30\%).

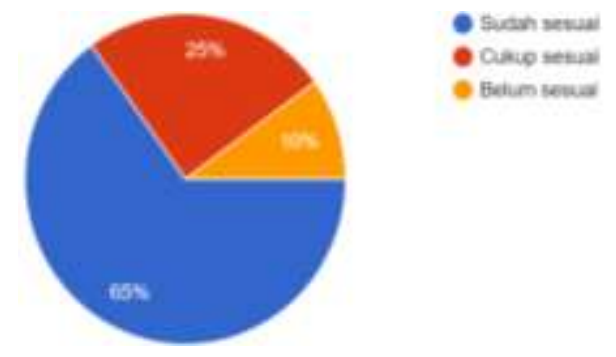

Gambar 6. Persentase implementasi TCK pengajar

Technological Content Knowledge (TCK), adalah bagaimana kesesuaian pengaturan pendidik dalam memadukan kemampuan teknologi dengan konten pembelajaran yang ada. Menurut respon yang terekam, terdapat pendidik yang telah menyediakan media pembelajan dan teknologi yang sangat sesuai dengan konten pembelajaran yang sedang dipelajari dan mengembangkan media pembelajaran melalui teknologi (65\%). Pengajar yang cukup mampu mengintegrasikan penggunaan teknologi dan konten materi pembelajaran (25\%) dan pengajar yang belum mampu mengintegrasikan media dan teknologi (10\%). Dalam kuisioner, responden menyatakan salah satu contoh pelaksanaan pembelajaran oleh pengajar yang sudah mampu mengintegrasikan teknologi dan materi pembelajaran adalah saat melakukan penelitian secara virtual, pengajar akan menyediakan software yang mudah digunakan, menandakan adanya inovasi teknologi sebagai media pembelajaran oleh pengajar.

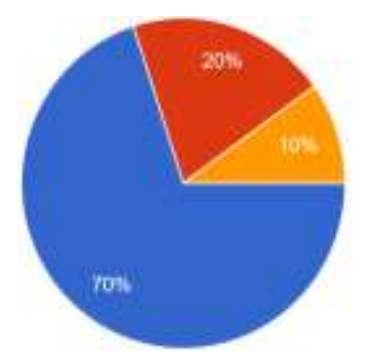

Sudah dilerapkan efektif Sucun diterapkan, betun - Beium dherzokan

Gambar 7. Persentase implementasi PCK pengajar

Pedagogical Content Knowledge (PCK), tingkat penguasaan keterampilan pedagogic dan kesesuaiannya dengan konten pembelajaran ditunjukan dengan persentase pengajar yang telah mampu mengimplementasikan PCK dengan efektif (70\%). 4 responden lainnya menyatakan penerapan PCK sudah diterapkan namun belum efektif (20\%) dan 2 responden beropini bahwa pengajar belum mampu 
menerapkan metode pembelajaran yang sesuai dengan materi pembelajaran (10\%). Dalan uraian yang dipaparkan oleh responden diantaranya perlunya peningkatan dalam menyesuaikan pendekatan metode pembelajaran pedagogic dengan materi yang akan disampaikan. Metode pembelajaran yang tidak relevan dengan konten pembelajaran akan mengakibatkan situasi belajar menjadi terkesan membosankan dan pengkonstruksian pemahaman mengenai materi menurun dan terjadinya ketidakevektifan pembelajaran.
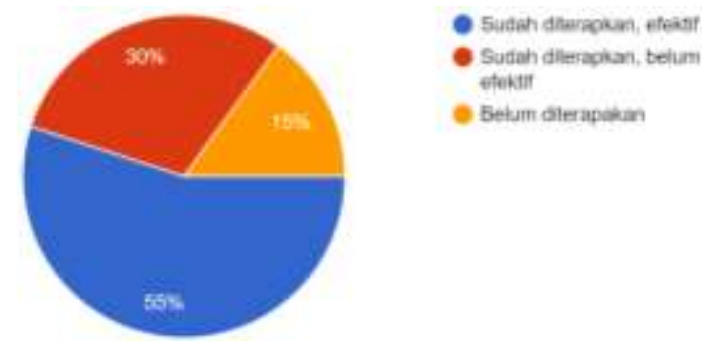
- Sutah dlerapian, belum

- Bekum dierapaka

Gambar 8. Persentase implementasi TPACK pengajar

Technological Pedagogical and Content Knowledge (TPACK), metode yang mengintegrasikan penguasaan kompetensi teknologi, pedagogik dan konten pembelajaran. TPACK lebih unggul dibandingkan PCK yang belum mengintegrasikan teknologi dalam kerangka teoretisnya. Keunggulan TPACK pada proses menyusun desain pembelajaran, model dan strategi pembelajaran, penilaian dan pengatur ulangan kurikulum yang terhubung dan menjadikan teknologi sebagai dasar acuan pengembangan pendidikan. Berdasarkan survei yang dilakukan, presentase penerapan TPACK yang efektif masih tergolong rendah (55\%). Selanjutnya, penilaian mahasiswa terhadap pengajar yang telah menerapkan TPACK namun belum mencapai keefektivan (30\%) dan dua responden menyatakan pengajar belum menerapkan sistem TPACK dalam kegiatan pembelajaran (15\%). Pendidik telah secara keseluruhan meninggalkan metode belajar konvensional. Pemanfaatan teknologi meskipun masih belum efektif, namun sedikit demi sedikit mulai dikembangkan dengan baik diintegrasikan sesuai dengan kebutuhan konten pembelajaran dan keterampilan mengatur kelas agar lebih kondusif. Persentase menunjukan masih banyaknya pengajar yang belum bisa menerapkan TPACK dan belum dikategorikan sangat menguasai. Mereka masih belum menguasai bagaimana mengintegrasikan komponen TPACK dalam praktik pembelajaran.

Kondisi ini yang seharusnya membuat generasi muda sadar mengenai peranannya di masa depan dan termotivasi untuk terus bergerak maju. Sebagus apapun kualitas pengajar, jika tidak didukung dengan kesadaran dan kemauan siswa untuk belajar, maka tidak akan meraih keefektivan pembelajaran. Berdasarkan penelitian yang telah dilakukan, dapat ditarik sebuah kesimpulan bahwa TPACK sudah terimplementasi dalam tingkat "cukup baik’ di Universitas Pendidikan Indonesia.

\section{KESIMPULAN DAN SARAN}

TPACK terdiri dari 7 komponen dan saling berelasi. Teknologi, pedagogik dan konten pembelajaran merupakan tiga hal utama yang mesti dikuasai oleh pendidik untuk menerapkan TPACK. Kesesuaian bagaimana pendidik menyampaikan materi dengan metode pembelajaran dan pemilihan media teknologi 
yang sesuai dan terstruktur. TPACK mengintegrasikan teknologi dalam mengolah pembelajaran kelas yang dulunya teori tersebut hanya menyangkut PCK (Pedagogical Content Knowledge). Dari penelitian ini, menandakan adanya modernisasi dalam kemajuan pendidikan di Indonesia dari sistem pembelajaran konvensional. Berdasarkan hasil penjabaran diatas, ditemukannya implementasi TPACK di Universitas Pendidikan Indoneseia, namun belum mencapai keefektivan yang maksimal. Hal ini menandakan, secara perlahan-lahan, modernisasi dalam bidang pendidikan merevitalisasi tatanan sistem konvensional dengan metode baru yang lebih relevan dan efektif perlu terus dikembangkan.

\section{REFERENSI}

Ahyar, H., Andriani, H., Sukmana, D; Hardani., Auliya, N; Andriani, H; Fardani, R. A., Ustiawaty, J., Utami, E. (2020). Buku Metode Penelitian Kualitatif \& Kuantitatif.

Ani, N. A. 2014. Pendidikan Karakter untuk Siswa SD dalam Perspektif Islam. Jurnal Mimbar Sekolah Dasar, 1(1), 50-58. (diakses 20 Juni 2021)

Farikah, F., \& Al Firdaus, M. M. 2020. Technological Pedagogical and Content Knowledge (TPACK): The Students' Perspective on Writing Class. Jurnal Studi Guru dan Pembelajaran, 3(2), 190-199. (diakses 20 Juni 2021)

Iskandar, I. 2018. MODERNISASI \& KELOMPOK MENENGAH INDONESIA. Jurnal REP (Riset Ekonomi
Pembangunan), 3(2), 334-346. (https://doi.org/10.31002/rep.v3i2.1041, (diakses 20 Juni 2021).

Matondang, A. 2019. Dampak Modernisasi Terhadap Kehidupan Masyarakat Sosial Masyarakat. Wahana Inovasi, 8(2), 189194. (diakses 20 Juni 2021).

Nasution, R. D. 2017. Pengaruh Modernisasi dan Globalisasi terhadap Perubahan Sosial Budaya di Indonesia. Jurnal Penelitian Komunikasi dan Opini Publik, 21(1), 3042. (diakses 20 Juni 2021).

Primadata, A. P., \& Kusumawati, D. K. 2014. Modernisasi Pendidikan di Indonesia sebuah Perspektif Sosiologis terhadap Dunia Pendidikan di Indonesia. Jurnal Analisa Sosiologi, 3, 25-51. (diakses 20 Juni 2021).

Rahmadi, I. F. 2019. Technological Pedagogical Content Knowledge ( TPACK): Kerangka Pengetahuan Guru Abad 21. Jurnal Pendidikan Kewarganegaraan, 6(1), 10. (diakses 20 Juni 2021).

Risdiany, H., \& Herlambang, Y. T. 2021. Pengembangan Profesionalisme Guru dalam Mewujudkan Kualitas Pendidikan di Indonesia. EDUKATIF: JURNAL ILMU PENDIDIKAN. 3(3), 817-822. (diakses 20 Juni 2020).

Rosyid, A. 2017. Technological Pedagogical Content Knowledge: Sebuah Kerangka Pengetahuan Bagi Guru Indonesia Di Era MEA. Prosiding Seminar Nasional Inovasi Pendidikan, 446-454. (diakses 20 Juni 2020). 
Sudira, P. 2012. Guru Sebagai Agen Modernisasi Pendidikan Dalam Dimensi Sosio-Kultural Untuk Peningkatan Kualitas Pendidikan. 1-15.

Wagner, T. 2008. The Global Achievment Gap (The Survival Skills for 21 Century). USA: World Press.

Depdikbud RI. Kamus Besar Bahasa Indonesia:

Kamus versi online/daring (dalam jaringan).

https://kbbi.web.id/modernisasi. (diakses 20 Juni 2020).

Faisal, I. 1998. Paradigma Kebudayaan Islam:

Studi Kritis dan Refleksi Historis. Yogyakarta: Titian Ilahi Press (hlm. 196).

Ritzer, George. 2000. Sociological Theory. McGraw-Hill Internasional Editions. Singapore. hlm. 557-558. (diakses 20 Juni 2020).

Chai, C., Koh, J. H., \& Tsai, C. 2013. A Review of Technological Pedagogical Content Knowledge. EducationalTechnology \& Society, 16 (2) (hlm. 31-51). (diakses 20 Juni 2020).

Kusumah, W. 2019. Menyiapkan Guru dan Dosen di Era Revolusi Industri 4.0, (Online), (https://www.kompasiana.com/wijayalab s/5dd36340d541df29bf6153c2/menyiapk an-guru-dan-dosen-di-era-revolusiindustri-4-0. (diakses pada 18 Juni 2021)

Mishra, P., \& Koehler, M. J. 2008. Introducing TPCK. AACTE Committee on Innovation and Technology. The handbook of technological pedagogical content knowledge (TPCK) for educators. Mahwah, NJ: Lawrence Erlbaum Associates (hlm. 3-29). (diakses pada 22 Juni 2020)

Schmidt, D. A., Baran, E., Thompson, A. D., Mishra, P., Koehler, M. J., \& Shin, T. S. 2009. Technological Pedagogical Content Knowledge (TPACK): The Development and Validation of an Assessment Instrument for Preservice Teachers. Journal of Research on Technology in Education, 42(2). (hlm. 123-149). (diakses pada 18 Juni 2020). 